\title{
Modelamiento del proceso de carbonatación del hormigón (UR- CORE), con datos de conversión fraccional obtenidos a través de experimentos de difracción de neutrones monitoreados in-situ
}

\section{Modelling of the carbonation of concrete (UR-CORE) from fractional conversion data obtained through in situ monitored neutron diffraction experiments}

\author{
Marta Castellote*1, Carmen Andrade \\ * Instituto de Ciencias de la Construcción Eduardo Torroja, IETcc, (CSIC). Madrid, ESPAÑA \\ Resumen \\ Contribución. Mejor artículo \\ Contribution. Best paper award \\ Conpat 2009 \\ PAG. 245 - 258

\begin{abstract}
Una de las principales causas de despasivación de las armaduras embebidas en hormigón es la denominada carbonatación, que consiste en la neutralización de la matriz de cemento como consecuencia de su interacción con el $\mathrm{CO}_{2}$ atmosférico. En este trabajo, se presenta un resumen del desarrollo de un modelo de carbonatación de las matrices de base cemento (UR-CORE). En primer lugar se ha llevado a cabo la carbonatación acelerada (al $100 \%$ de $\mathrm{CO}_{2}$ ) sobre probetas de pasta de cemento con distintas matrices cementantes tomando espectros de Difracción de Neutrones a lo largo del tiempo de experimento. La evolución de la intensidad de los picos correspondientes a cada una de las fases involucradas ha proporcionado datos de conversión fraccional en tiempo real, lo que ha posibilitado una aproximación cinética al fenómeno de la carbonatación y el desarrollo del modelo UR-CORE, basado en los principios de los sistemas de "núcleo sin reaccionar", típicos de los procesos en ingeniería química.
\end{abstract}

Palabras Clave: Carbonatación acelerada, monitorización in-situ, difracción de neutrones, modelización, UR-CORE

Abstract

One of the most important depassivation mechanisms of steel reinforcement in concrete is that caused by the neutralisation of the cement matrix. In this work, a summary of the development of a model for the carbonation of cementitious matrixes (UR-CORE) is presented. On one hand, in-situ monitoring of the changes that take place in the phase composition of cement pastes during accelerated carbonation $\left(\mathbf{1 0 0} \% \mathrm{CO}_{2}\right)$ for different binders, is reported, by taking Neutron Diffraction patterns in parallel with the carbonation experiments. The variation of the intensity of chosen reflections for each phase along the experiment supplied data, in real time, for fractional conversion of different phases. On the second hand, fitting of these results allowed to make a quantitative approach to the kinetics of the carbonation of the different phases, and develop the UR-CORE model that is based on the principles of the "unreacted-core" systems, typical of chemical engineering processes.

Keywords: Accelerated carbonation, in situ monitoring, neutron diffraction, modelling, UR-CORE

\section{Introducción}

La carbonatación del hormigón, como consecuencia de su interacción con el gas carbónico $\mathrm{CO}_{2}$, ha sido considerada durante años como tema de interés en las investigaciones químicas del cemento (Tokyay, 1997; Alonso et al., 1988). El proceso conocido como carbonatación, es un proceso fisicoquímico complejo que modifica lentamente la estructura del hormigón, a través del tiempo, e induce a cambios en sus propiedades físicas (Pihlajavaara, 1998; Houst y Wittmann, 2002)

\section{Introduction}

Carbonation of concrete, as consequence of its interaction with the atmospheric $\mathrm{CO}_{2}$, has been considered for years a subject of interest in researches of cement chemistry (Tokyay, 1997; Alonso et al., 1988). The process known as carbonation, is a complex physicochemical process that slowly modifies the structure of the concrete in the course of time and induces changes into its physical (Pihlajavaara, 1998; Houst and Wittmann, 2002)

1 Autor de correspondencia / Corresponding author: 
y químicas (Susuki et al., 1989; Richardson et al., 1993; Nishikawa y Suzuki, 1991; Kobayashi et al., 1994; Kim et al., 1995; Groves et al., 1991; Sergi, 1986; Berger, 1979; Sauman y Lach, 1972; Cole y Kroone, 1959; Cole y Kroone, 1960).

A pesar que se han realizado muchas investigaciones sobre el tema, en relación a la predicción de la carbonatación prematura del frente, o sobre el cálculo de la vida útil del hormigón reforzado, aún existen dudas fundamentales, debido a que surgen dos problemas: por un lado, se asume que la carbonatación es principalmente un fenómeno disfuncional, donde el frente carbonatado se mueve hacia el interior del hormigón en una relación proporcional a la raíz cuadrada del tiempo (Rahman y Glasser, 1989; Venuat y Alexandre, 1968; Weber, 1983; Smolczyck, 1968). Además de la simple expresión raíz cuadrada del tiempo, se puede encontrar literatura sobre un sinnúmero de modelos de vida útil, siendo los más empleados, los citados en (Tuuti, 1982; Bakker, 1964; Parrot, 1994). Algunos emplean el coeficiente de difusión como un parámetro de transporte básico (Tuuti, 1982; Bakker, 1964), mientras otros usan el coeficiente de permeabilidad del aire (Parrot 1994). Recientemente, se ha propuesto un modelo basado en el uso de la resistividad (Andrade et al., 2000). Sin embargo, no se ha encontrado literatura con demostraciones experimentales confiables sobre los resultados a corto plazo para predecir resultados en el largo plazo, considerando que existe una estimación excesiva de los resultados previstos a largo plazo (Sanjuan et al., 2003).

Por otra parte, no existe un método generalmente aceptado, debido a que la carbonatación natural es un proceso verdaderamente consumidor de tiempo; la carbonatación acelerada empleando mayores concentraciones de $\mathrm{CO}_{2}$ es una práctica común en la mayoría de los laboratorios, por lo que existen muchas dudas sobre la validez de las pruebas de carbonatación acelerada que permitan extrapolar resultados a condiciones naturales. Lo anterior, principalmente debido a que la micro-estructura existente de las pastas carbonatadas que emplean $\mathrm{CO}_{2}$ puro, es diferente de aquellas pastas aerocarbonatadas (Suzuki et al., 1989; Groves et al., 1991; Bier et al., 1989; Sergi, 1986; Verbeck, 1958; Sanjuan et al., 2003; Catellote (a) et al.,2008), incluso las cantidades resultantes de material carbonatado aumenta cuando se incrementa la concentración de $\mathrm{CO}_{2}$ (Castellote (a) et al.)

Este artículo presenta el resumen de un modelo de carbonatación para matrices de hormigón basado en los principios de sistemas "núcleo sin reaccionar", and chemical (Susuki et al., 1989; Richardson et al., 1993; Nishikawa y Suzuki, 1991; Kobayashi et al., 1994; Kim et al., 1995; Groves et al., 1991; Sergi, 1986; Berger, 1979; Sauman and Lach, 1972; Cole y Kroone, 1959; Cole and Kroone, 1960) properties.

Despite much research carried out on the subject, related to the prediction of the advance of the carbonation front, or on service life calculation of reinforced concrete, there is still fundamental doubts, as two main problems arise: On one hand, carbonation is assumed to be, mainly, a diffusional phenomenon, where the carbonation front moves inwards the concrete at a rate proportional to the square root of time (Rahman and Glasser, 1989; Venuat and Alexandre, 1968; Weber, 1983; Smolczyck, 1968). In addition to the simple square root of time expression, several service life models can be found in literature, being some of the most used those given in (Tuuti, 1982; Bakker, 1964; Parrot, 1994). Some of them use the diffusion coefficient as the basic transport parameter (Tuuti, 1982; Bakker, 1964), while others use the air permeability coefficient (Parrot 1994). More recently, a model based in the use of the resistivity has been also proposed (Andrade et al., 2000). However, no experimental results have been found in literature on the reliability of the short term results for predicting long term results, finding a general overestimation of the predicted results at long term (Sanjuan et al., 2003).

On the other hand, there is not a generally accepted test method, mainly due to the fact that the natural carbonation is a very time consuming process and accelerated carbonation, using higher $\mathrm{CO}_{2}$ concentrations, is a common practice in most of laboratories, existing many doubts on the validity of the accelerated tests to extrapolate results in natural conditions. This is due mainly to the fact that the resulting microstructure of pastes carbonated using pure $\mathrm{CO}_{2}$ is different that those of air-carbonated pastes (Suzuki et al., 1989; Groves et al., 1991; Bier et al., 1989; Sergi, 1986; Verbeck, 1958; Sanjuan et al., 2003; Catellote et al.,2008), and even the resulting amount of carbonated material increases when increasing the $\mathrm{CO} 2$ concentration (Castellote (a) et al.).

This paper presents the summary of a model for the carbonation of cementitious matrixes based on the principles of the "unreacted-core" systems, 
en los que el producto reactivo permanece sólido como una capa de ceniza inerte, adaptado al caso específico de carbonatación, UR-CORE (Castellote y Andrade, 2008). El desarrollo del modelo ha sido posible a través del control de los experimentos in-situ, empleando difracción de neutrones, pruebas de carbonatación aceleradas, al $100 \%$ de concentración de $\mathrm{CO}_{2}$ en pastas de cementos con diferentes aglomerantes (Castellote et al., 2008). En Castellote et al., 2008 y Castellote y Andrade, 2008, se encuentra una detallada explicación sobre experimentos in-situ de difracción de neutrones y sobre el desarrollo del modelo. En este artículo, se presenta un resumen de los elementos esenciales del modelo, en conjunto con la conversión fraccional, para las distintas fases de las pastas de cementos, obtenidas a través de los experimentos in-situ.

\section{Procedimiento experimental}

\subsection{Materiales y preparación de las muestras}

Para los experimentos de carbonatación in-situ, las pastas de cemento (con tres tipos de aglomerantes distintos), fueron preparadas a mano y mezcladas con

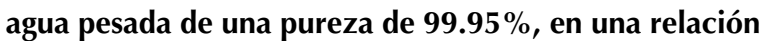
agua-cemento de 0.5. El primer aglomerante fue el cemento Portland tipo I/45A/SR-MR, que tiene una adición de $5 \%$ de caliza. El segundo aglomerante, es una mezcla OPC-FA de cemento Portland con cenizas volantes; fue preparado empleando el mismo cemento y substituyendo un $35 \%$ por cenizas volantes. El tercer tipo, es una mezcla OPC-MS, nuevamente se utilizó el cemento Portland con una substitución del $\mathbf{1 0} \%$ de micro-sílice. Los análisis químicos para el cemento, cenizas volantes y el microsílice se muestran en la Tabla 1.

Estas probetas de pastas fueron moldeadas en probetas plásticas cilíndricas, sellados, con el fin de evitar la carbonatación, y dejados curar durante 28 días, a temperatura ambiente $\left(22^{\circ} \mathrm{C}\right)$, en una cámara húmeda (HR> 95\%). Las probetas cilíndricas resultantes fueron de $9 \mathrm{~mm} \phi$ y $32 \mathrm{~mm}$ de alto. in which the reacted product remains in the solid as a layer of inert ash, adapted to the specific case of carbonation, UR-CORE (Castellote y Andrade, 2008). The development of the model has been possible through the in situ monitoring, by neutron diffraction, of accelerated carbonation tests, at $100 \% \mathrm{CO}_{2}$ concentration, of cement pastes with different binders (Castellote et al., 2008). In Castellote et al., 2008 and Castellote and Andrade, 2008, detailed explanation of the in-situ neutron diffraction experiments and on the development of the model are given. In this paper, a summary of the essentials of the model in conjunction with the fractional conversion, for different phases of the cement pastes, obtained through the in-situ experiments is presented.

\section{Experimental procedure}

\subsection{Materials and preparation of specimens}

For the in-situ carbonation experiments [54], cement pastes (with three different types of binder) were prepared by hand mixing with deuterated water from $99.95 \%$ purity to a $w / c$ ratio of 0.5 . The first binder was plain OPC cement type I/45A/SR-MR, having a $5 \%$ of addition of lime. The second one, mix OPC-FA, was prepared using the same cement substituted in a $35 \%$ by fly ash. The third type, mix OPC-MS, was used again the same cement with a substitution of a $10 \%$ by microsilica. The chemical analyses of the Cement, Fly Ash and Micro-Silica, are given in Table 1.

These paste specimens were cast in cylindrical plastic moulds, which were sealed, in order to avoid carbonation, and allowed to cure for 28 days at room temperature $\left(22^{\circ} \mathrm{C}\right)$ in a humid chamber $(\mathrm{HR}>95 \%)$. The resulting specimens were cylindrical, $9 \mathrm{~mm} \phi$ and 32 mm height.

Tabla 1. Análisis químico para el cemento, ceniza volante y micro-sílice, empleados Table 1. Chemical analysis of the cement, fly ash and micro-silica used

\begin{tabular}{||l|c|c|c|c|c|c|c|c|c|c||}
\hline Cemento/Cement & $\mathrm{SiO}_{2}$ & $\mathrm{Al}_{2} \mathrm{O}_{3}$ & $\mathrm{Fe}_{2} \mathrm{O}_{3}$ & $\mathrm{CaO}$ & $\mathrm{MgO}$ & $\mathrm{SO}_{2}$ & $\mathrm{Cl}^{-}$ & $\mathrm{Na}_{2} \mathrm{O}$ & $\mathrm{K}_{2} \mathrm{O}$ & free $\mathrm{CaO}$ \\
\hline I/45A/SR-MR & 20.2 & 2.37 & 4.1 & 65.84 & 1.85 & 3.8 & 0.02 & 0.11 & 0.65 & 1.5 \\
\hline Ceniza Volante/ & 48.71 & 25.18 & 5.18 & 12.09 & 1.61 & 0.43 & --- & 0.61 & 3.28 & 0.15 \\
\hline Micro-Sílice/Micro-Silica & 96.32 & 0.00 & --- & 0.67 & 0.49 & --- & --- & 0.15 & 0.39 & 0.04 \\
\hline \hline
\end{tabular}




\subsection{Técnicas y Procedimientos}

Las probetas de agua pesada de cada mezcla, luego de ser curadas y desmoldadas, continuaron selladas para evitar la carbonatación, hasta el momento de los ensayos experimentales in-situ que tuvieron lugar 130 días después de ser moldeadas.

Para realizar los experimentos de carbonatación, se diseñó una mini-cámara de vidrio, que consistente en un cuerpo cilíndrico con un tubo y una válvula en el fondo. La mini-cámara contaba con un vidrio perforado cuya función era separar el cuerpo del aparato de la válvula (que permitía el Ilenado del fondo), con un $65 \%$ de solución saturada de Nitrato Sódico $\left(\mathrm{NaNO}_{3}\right)$, que se mantuvo separada de la muestra. El aparato poseía una tapa hermética donde la muestra era suspendida y tres orificios de entrada (entrada de $\mathrm{CO}_{2}$, salida de $\mathrm{CO}_{2}$ y ventilación). El gas $\mathrm{CO}_{2}$ era suministrado a una concentración del $100 \%$, a través de un tubo cubierto con una lámina de cadmio (para evitar las interferencias del tubo plástico con los neutrones) en el fondo del aparato cilíndrico, con el fin de asegurar la correcta circulación de gas a través de la muestra.

La carbonatación in-situ fue monitoreada en línea con modelos adquiridos y simultáneos de difracción de neutrones, por el equipo D20 del Institute Max von Laue - Paul Langevin (ILL), Grenoble, Francia, por lo tanto los patrones de difracción fueron analizados con procedimientos estandarizados. Las fases cristalinas fueron identificadas por el procedimiento manual de búsqueda y correspondencia; los máximos seleccionados para portlandita, calcita, etringita y silicatos de calcio hidratados, fueron Ilevados a curvas Gaussianas en todas las series. La variación de intensidad de una reflexión seleccionada en una fase particular, a lo largo del experimento (en relación con la concentración), fue empleada para monitorear los cambios de concentración.

\subsection{Modelo de Carbonatación}

En una forma simplificada, las matrices de base cemento pueden ser definidas como un sistema de reacción heterogéneo, en el cual varias fases sólidas de la nuestra reaccionan paralelamente con el gas carbónico $\mathrm{CO}_{2}$. Sin embargo, siendo más realistas, este es un proceso bastante más complejo, que puede diferir considerablemente de las ecuaciones estequiometricas. De hecho, en este tipo de sistemas heterogéneos, el índice general de la expresión se torna muy complicado debido a la interacción entre los procesos físicos y químicos. Esto es introducido en los modelos, como el requisito que los reactores de una fase deban ser transportados a la siguiente fase, la cual posee otros reactores productores de reacciones. E n e I

\subsection{Techniques and procedures}

After curing and demoulding, the deuterated specimens of every mix were kept sealed, in order to avoid carbonation, until the in-situ experimental trials, that took place 130 after casting them.

A glassed mini-carbonation-chamber was designed for the carbonation experiments, consisting in a cylindrical body with a tube and a valve in its bottom. It has a perforated glass separating the body of the device and the valve that allows filling in the bottom part with the $65 \%$ HR regulation solution (saturated solution of $\mathrm{NaNO}_{3}$ ) keeping it separated from the specimen. The device has a hermetic cap, where the sample was suspended, with three inlets (inlet of $\mathrm{CO}_{2}$, outlet of $\mathrm{CO}_{2}$ and aeration). The $\mathrm{CO}_{2}$ gas was delivered at a concentration of $100 \%$, through a tube, covered by a sheet of cadmium (for avoiding interferences of the plastic tube with the neutrons), at the bottom of the cylindrical device, in order to assure the right circulation of the gas through the sample.

The in-situ carbonation was followed on line by simultaneous acquisition of diffraction patterns at the D20 instrument of the Institute Max von Laue - Paul Langevin (ILL), in Grenoble, France, and the powder diffraction patterns were analysed by a standard procedure. Crystalline phases were identified by a search-match manual procedure and selected peaks for Portlandite, Calcite, Ettringite and a Calcium silicate hydrate were fitted to Gaussian curves for the whole series. The variation of intensity of a chosen reflection for a particular phase along the experiment (related with the concentration) has been used to monitor concentration changes.

\subsection{Carbonation Model}

In a simplified way, carbonation of a cementitious matrix can be considered as a heterogeneous reaction system in which several solid phases of the sample react in parallel with the $\mathrm{CO}_{2}$ (gas). However, as most real processes, this is a quite complex system, that can differ considerably from the stoichiometric equations. In fact, in this type of heterogeneous systems, the overall rate expression becomes complicated because of interaction between physical and chemical processes. This is introduced, in the models, by the requirement that reactants in one phase have to be transported to the other phase containing other reactants where the reactions take place. 
campo de la ingeniería química, varios modelos matemáticos describen reacciones gas-sólido.

Entre ellos, los modelos simplificados del tipo "núcleo sin reaccionar", han demostrado representar el comportamiento real del producto reactor, que en la mayoría de los casos permanece en estado sólido como una capa de ceniza inerte, tal como ocurre en el caso de la carbonatación. Sin embargo, es necesario tener presente que los perfiles TG han demostrado que más bien existe una zona de transición que una interface aguda (Rahman y Glasser, 1989; Parrott, 1992; Houst y Wittmann, 2002) en el frente carbonatado. Sin embargo, también es adecuado medir el frente carbonatado con indicadores químicos (fenolftaleína) para pruebas de profundidad estándar, ya que probablemente proporciona el mejor indicador en lo que se refiere a la despasivación general del acero (Rahman y Glasser 1989).

Por lo tanto, se considera lograda la principal premisa del modelo de núcleo sin reaccionar. Entonces se puede aplicar y se puede formular el índice de expresión general, tomando en cuenta los pasos inherentes al proceso, que son:

a) Difusión a través de la película de gas: Difusión de gas reactivo, $\mathrm{CO}_{2}$, a granel, desde la primera fase (gaseosa) a la interface, entre las fases gaseosa-líquida.

b) Penetración y difusión del gas por la capa ceniza hacia la superficie del núcleo, aún sin reaccionar (difusión del $\mathrm{CO}_{2}$, a través del frente carbonatado de la muestra).

c) Reacción química entre reactores.

d) Difusión de los productos resultantes que no precipitan al formar la capa de ceniza (vapor de agua/líquido liberado durante la reacción), desde la superficie de los núcleos sin reaccionar hacia a superficie externa.

e) Difusión de estos productos no sólidos, a través de la película de gas.

Estos pasos han sido esquemáticamente representados en la Figura 1, la cual también muestra la zona de transición de la superficie del "núcleo sin reaccionar". La parte izquierda de la figura, muestra el cambio de la concentración de reactor de gas $\left(\mathrm{CO}_{2}\right)$ para los pasos a), b) y c) mientras que la parte derecha de la figura muestra los pasos en la formación de producto nosolido c), d) y e).

Considerar la resistencia de todos los pasos, dificultaría la resolución del problema, ya que la resistencia es normalmente muy diferente en cada paso; el más lento es el controlador y determinará el índice global del proceso.
There are various mathematical models, in the field of the chemical engineering, for the description of the gas-solid reactions.

Among them, simplified models of the type "unreacted-core" have proved to represent the actual behaviour closely, in most cases in which the reacted product remains in the solid as a layer of inert ash, as it is the case of carbonation. However, itt is necessary to be aware that it has been proved, by TG profiles, that there is a transitional zone rather than a sharp interface (Rahman and Glasser, 1989; Parrott, 1992; Houst and Wittmann, 2002) in the carbonation front. However, testing the carbonation front using chemical indicators (phenolphthalein) is also satisfactory for standard depth of carbonation tests and probably gives the best indication as far as the overall depassivation of the steel is concerned (Rahman y Glasser 1989).

Therefore, the main premise of an unreactedcore model is considered to be accomplished enough. Thus, it can be applied and the overall rate expression may be formulated by considering the successive steps involved in the process, that are the following ones:

a) Diffusion through the gas film: Diffusion of gaseous reactant, $\mathrm{CO}_{2}$, from the bulk of the first phase (phase gas) to the interface between the two phases (gas-solid).

b) Penetration and diffusion of the gas through the ash shell to the surface of the core not yet reacted (Diffusion of $\mathrm{CO}_{2}$ through the external carbonated part of the sample).

c) Chemical reaction between the reactants. d) Diffusion of the products formed that do not precipitate to form the ash shell (water vapour/liquid released in the reaction) from the surface of the unreacted core towards the external surface.

e) Diffusion of these non solid products through the gas film.

These steps have been schematically represented in figure 1, in which the transitional zone in the surface of the unreacted core has also been depicted. In the left part of the figure, the change in the concentration of the reactant gas $\left(\mathrm{CO}_{2}\right)$ have been depicted for the steps a), b) and c) while the right part of the figure shows the steps c), d) and e) for the water formed.

Considering the resistance of all this steps would make the problem very difficult to solve, and that the resistance of the different steps normally is quite different, the slowest step is the controlling one and will determine the rate of the global process. 


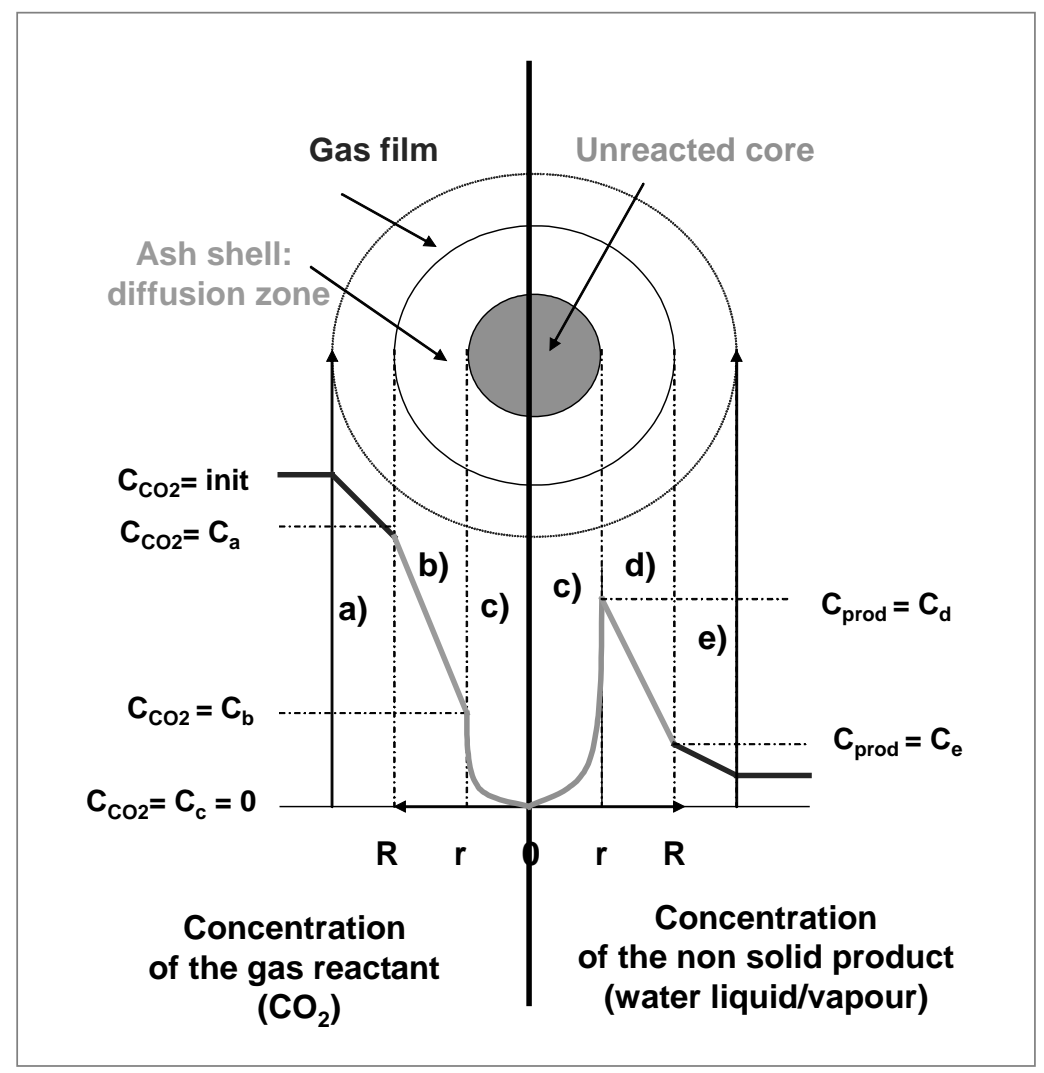

Figura 1. Representación esquemática de los sucesivos pasos inherentes al modelo "núcleo sin reaccionar". En la parte izquierda de la figura: cambio de concentración del reactor de gas $\left(\mathrm{CO}_{2}\right)$ para los pasos a), b) y c). En la parte derecha: pasos para la formación del producto no-solido c), d) y e)

Figure 1. Schematic representation of the successive steps involved in the unreacted-core model. In the left part, change in the concentration of the reactant gas (CO2) for the different steps $(a, b$ and $c)$. In the right part, steps c), d) and e) for a non- solid product formed

En el caso de matrices de base cemento carbonatadas, los pasos de la difusión a través de la película de gas (pasos a) y e)) pueden ser directamente descuidados. En relación al paso d), la mayoría de los productos en el proceso de carbonatación corresponden a fases sólidas. El único fluido es el agua resultante, cuya liberación depende de la humedad relativa del ambiente de carbonatación, que se sabe influencia en gran medida la velocidad global. Dado que los experimentos aquí informados han sido desarrollados en una constante $\mathbf{R H}$, este paso no será tomado en esta etapa. Sin embargo, es un punto a ser incorporado en el modelo.

Por lo tanto, los pasos considerados son: paso b) difusión del $\mathrm{CO}_{2}$ a través del frente carbonatado y c) reacción química. Estos pasos deben ser expresados como diferenciales del equilibrio de material, en el cual la difusión a través de las cenizas es representada por la primera ley de Fick y considera reacciones químicas de primer orden.
In the case of carbonation of cementitious matrixes, the steps of the diffusion through the gas film (steps a) and e)) can be directly neglected. Concerning step d), most of the products of the carbonation process are solid phases. The only fluid product is the water formed, whose release depends on the relative humidity of the environment where carbonation is taking place, which is known to strongly influence the global speed. Provided that the experiments reported here have been carried out at constant HR, this step will not be taken into account at this time. However, this is an important point to be incorporated in the model.

Therefore, the steps to be taken into account are: step b) diffusion of $\mathrm{CO}_{2}$ through the carbonated part and c) Chemical reaction. These steps have to be expressed as differential material balances, in which the diffusion through the ashes is represented by the first Fick's law and considering the chemical reactions of first order. 


\section{Resultados y discusión}

\subsection{Los Modelos de Difracción de Neutrones}

El análisis de los modelos de difracción de neutrones ha permitido la identificación de $\mathbf{4}$ fases de cristales principales: portlandita, calcita, etringita y una forma cristalina de silicatos de calcio hidratados (CSH gel). No se determinó cemento sin hidratar en forma clara (Castellote et al., 2008).

Los índices máximos fueron llevados a curvas Gaussianas en todas las series. La variación de intensidad de la reflexión seleccionada en una fase determinada, durante el experimento fue empleada para monitorear los cambios de concentración. Como ejemplo, la Figura 2, muestra la evolución de la intensidad normalizada en función del tiempo de carbonatación en la mezcla Portland y las cuatro fases cristalinas fueron analizadas. En la Figura 2, se puede apreciar que la carbonatación implica la reducción simultánea de la portlandita, etringita, del gel CSH mientras que la calcita aumentó progresivamente (tomar en cuenta que la intensidad normalizada de la calcita no es cero, debido a la cantidad inicial de caliza en el cemento).

\section{Results and discussion}

\subsection{Neutron diffraction patterns}

The analysis of the neutron diffraction patterns has allowed the identification of $\mathbf{4}$ main crystal phases: Portlandite, Calcite, Ettringite, and a form of crystalline Hydrated Calcium silicate (CSH gel). No anhydrous cement was clearly resolved (Castellote et al., 2008).

These peaks have been fitted to Gaussian curves for the whole series. The variation of intensity of a chosen reflection for a particular phase along the experiment (related with the concentration) was used to monitor concentration changes. As an example, Figure 2 shows the evolution of the normalised intensity as a function of the time of carbonation for the OPC mix and for the four crystalline phases analysed. In Figure 2 , it can be seen that carbonation implies the simultaneous reduction of the Portlandite, Ettringite and $\mathrm{CSH}$ gel while Calcite increases progressively (note that the initial normalised intensity for calcite is not zero due to an initial amount of lime in the cement).

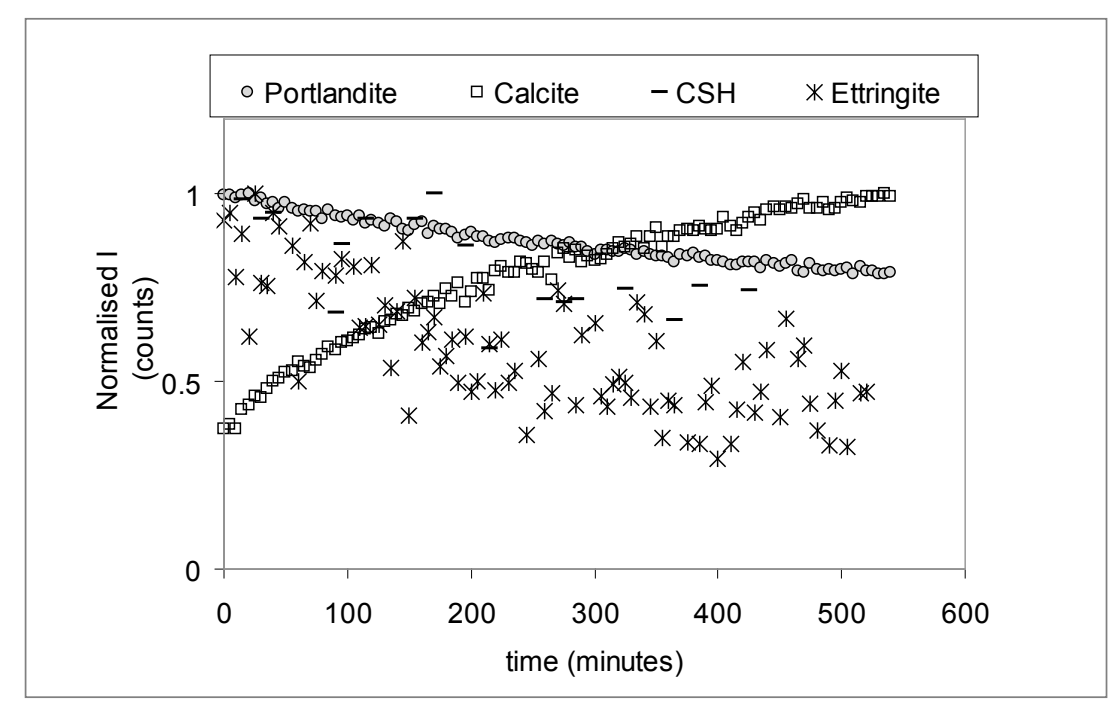

Figura 2. Evolución de la intensidad normalizada para la mezcla Portland, en función del tiempo de carbonatación para las cuatro fases analizadas de cristales

Figure 2. Evolution of the normalised intensity for the OPC mix as a function of the time of carbonation for the four crystalline phases analysed

\subsection{Desarrollo del modelo}

Aunque existe literatura con muchos modelos propuestos para predecir la aparición del frente carbonatado en matrices de base cemento, la validez de experimentos acelerados para extrapolar resultados al proceso de condiciones normales aún es dudoso;

\subsection{Development of the model}

Even though several models have been proposed in literature to predict the advance of the carbonation front in cementitious matrixes, the validity of the accelerated tests to extrapolate results in natural conditions continues to be very doubtful, 
no se ha encontrado literatura sobre un modelo válido que permita emplear resultados experimentales con el fin de predecir la proporción de carbonatación en otras situaciones. Este es el objetivo del modelo UR-Core (Castellote y Andrade, 2008) para índice de carbonatación, que ha sido desarrollado en tres etapas:

a) Establecimiento del paso controlador en el índice global de carbonización.

b) Adaptación del modelo al problema específico de matrices de cemento.

c) Validación del modelo.

3.2 a) Establecimiento del paso controlador en el índice global de carbonatación

Según el modelo propuesto "núcleo sin reaccionar" (UR-Core), el índice de expresión general es formulado a partir de una serie de pasos sucesivos. Sin embargo, para obtener una solución al problema, es necesario simplificar el fenómeno físico e identificar el paso más lento que finalmente es el controlador y determinante del índice global del proceso. Como se explicó en la sección experimental, los pasos a ser analizados durante la carbonatación de matrices de cemento y que podrían controlar el proceso, son identificados como b) difusión de $\mathrm{CO}_{2}$ a través de la zona carbonatada y c) reacción química, donde cada caso posee ecuaciones integradas (Castellote y Andrade, 2008).

Los resultados de difracción in-situ de neutrones proporcionan datos cinéticos sobre conversión fraccional en las distintas fases, facilitando por primera vez la identificación del paso controlador, comparando los resultados experimentales con los resultados de las ecuaciones teóricas. Para privilegiar la claridad, la comparación ha sido realizada en forma gráfica: Las ecuaciones teóricas de una probeta cilíndrica han sido dibujadas en la Figura 4, donde el mejor ajuste de datos experimentales, comparado con curvas teóricas, ha sido dibujado para la mezcla Portland con cenizas volantes (OPC-FA), como ejemplo de comportamiento para diferentes muestras.

De la Figura 3 se puede deducir que el paso controlador es aquel de difusión del $\mathrm{CO}_{2}$ a través de la zona carbonatada en la muestra, y se ajusta bastante bien a la ecuación teórica para los tres tipos de cemento. Este es el mismo tipo de comportamiento para las otras dos fases: cristales de etringita e hidrato de silicato de calcio (HSC gel), solamente presentes en el cemento Portland. not having found in literature any validated model able to use data of tests, in any condition, for predicting the rate of carbonation in any other situation. This is the objective of the UR-CORE model (Castellote y Andrade, 2008) of the carbonation rate, that has been undertaken in three steps:

a) Establishment of the controlling step in the global carbonation rate.

b) Adaptation of the model to the specific problem of cementitious matrixes

c) Validation of the model

3.2 a) Establishment of the controlling step in the global carbonation rate

According to the unreacted core model proposed, the overall rate expression is formulated by considering a series of successive steps. However, in order to have a solvable problem, it is necessary to simplify the physical phenomena and identify the slowest step that is the controlling one, and will determine the rate of the global process.

As explained in the experimental section, in the case of carbonation of cementitious matrixes, the steps to be analysed, that could control the process, are the steps labelled as b) diffusion of $\mathrm{CO}_{2}$ through the carbonated part, and c) chemical reaction, having each case different integrated equations (Castellote y Andrade, 2008).

The in situ neutron diffraction results provide the kinetic data of fractional conversion for the different phases, making it possible, for the first time, to discriminate the controlling step by comparing the experimental results with the corresponding theoretical equations. For the sake of clarity, the comparison has been done in a graphical way: The theoretical equations for a cylindrical specimen have been depicted in Figure 4, where the best fit of the experimental data in comparison with the theoretical curves has been depicted for mix OPC-FA, as an example of the behaviour for the different mixes.

From Figure 3, it can be deduced that the controlling step is that of diffusion of the $\mathrm{CO}_{2}$ through the carbonated part of the sample, fitting very well the theoretical equation for the three types of cement. This type of behaviour is the same for the other two phases: Ettringite and CSH (only available for OPC). 
Se esperaba que ((Parrott, 1992), que para obtener condiciones ambientales normales de $\mathrm{CO}_{2}$ y humedad relativa, la carbonatación fuera controlada por difusión de gas, a través de poros vanos en la capa de la superficie) el índice de carbonatación fuera un proceso controlador de difusión. Sin embargo, aquí ha quedado demostrado que el paso controlador del índice de carbonatación es la difusión del $\mathrm{CO}_{2}$, a través de la zona carbonatada externa de la muestra, lo que revalida el empleo de la simple ley de raíz cuadrada del tiempo (Rahman y Glasser, 1989; Venuat y Alexandre, 1968; Weber, 1983; Smolczyck, 1968), para describir el avance en el frente bajo condiciones determinadas, por lo tanto, el conjunto de ecuaciones aplicables para muestras cilíndricas son:
It was expected (in (Parrott, 1992), it was stated that under normal environmental conditions of $\mathrm{CO}_{2}$ and relative humidity, carbonation was controlled by gas diffusion through the empty pores in the surface layer) that the rate of the carbonation was a diffusion controlled process. However, here it has been demonstrated that the controlling step in the carbonation rate is the diffusion of the $\mathrm{CO}_{2}$ through the external carbonated part of the sample, that revalidates the simplified use of the simple law of the square root of time (Rahman y Glasser, 1989; Venuat y Alexandre, 1968; Weber, 1983; Smolczyck, 1968), to describe the advance of the front in given conditions, and therefore, the set of equations to apply for a cylindrical specimens are:

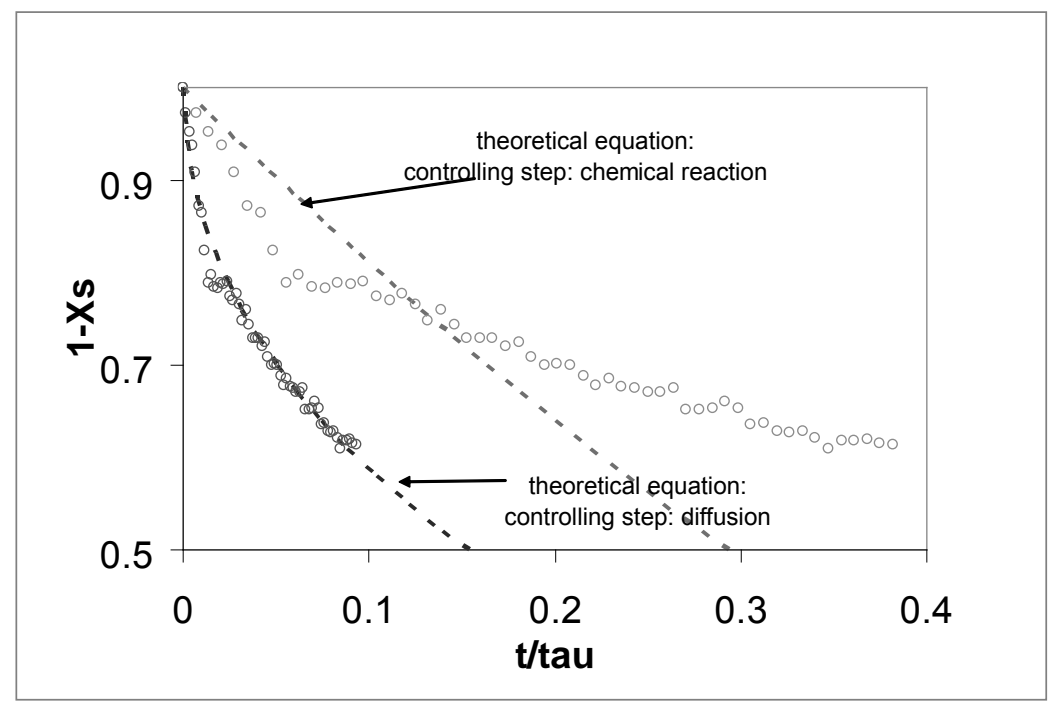

Figura 3. Presentación gráfica de las ecuaciones teóricas en una probeta cilíndrica y el mejor ajuste de los datos experimentales, obtenidos por difracción de neutrones en mezclas de hidróxido de calcio y de cemento Portland con cenizas volantes OCF-FA

Figure 3. Graphical presentation of theoretical equations for a cylindrical specimen and best fitting of the experimental data obtained by neutron diffraction, for portlandite and OCF-FA mix, to these equations

$$
\begin{gathered}
X_{S}=1-\left(\frac{r}{R}\right)^{2} \\
\frac{t}{\tau}=X_{S}+\left(1-X_{S}\right) \ln \left(1-X_{S}\right) \\
\tau=\frac{\rho_{S} R^{2}}{4 b D C_{C O 2}}
\end{gathered}
$$

Donde:

$\mathrm{X}_{\mathrm{s}}$ : Conversión fraccional del reactor sólido - s; en tiempo $-t$
Where:

$X_{s}$ : Fractional conversion of the solid reactant, $s$, at time t. 
$\rho_{s}$ : Fracción molecular del reactor $-s$, en el sólido $\left(\mathrm{mol} / \mathrm{cm}^{3}\right)$

t: Tiempo del experimento (seg.)

$\tau$ : Tiempo total para la conversión del reactor $-\mathbf{s}$ (seg.)

D: Coeficiente efectivo de difusión de $\mathrm{CO}_{2}$ a través de la capa carbonatada $\left(\mathrm{cm}^{2} / \mathrm{seg}\right)$

b : Coeficiente estequiométrico para la reacción: b S(s) $+\mathrm{CO}_{2} \rightarrow \ldots$.

$\mathrm{CC}_{\mathrm{O} 2}$ : Concentración of $\mathrm{CO}_{2}$ en la fase gaseosa $\left(\mathrm{mol} / \mathrm{cm}^{3}\right)$

r: Radio de núcleo sin reaccionar $(\mathrm{cm})$

R: Radio del cilindro $(\mathrm{cm})$

3.2 b) Adaptación y aplicación del modelo de materiales de cemento empleando distintas concentraciones de $\mathrm{CO}_{2}$

A partir de datos experimentales y del conjunto de ecuaciones 1,2 y 3 , es posible determinar el tiempo total de conversión en cada fase, del cual se deduce que existe la misma proporcionalidad entre cada fase de distintas muestras (Castellote y Andrade, 2008), aunque sea la misma mezcla y el índice sea diferente en las distintas fases. Sosteniendo que el paso controlador es la difusión de $\mathrm{CO}_{2}$, a través del frente carbonatado de la muestra, los diferentes $\tau$ no son el resultado de distintos índices de reacciones químicas, si no que son atribuibles a diferentes fracciones moleculares en cada fase del reactor, donde $\mathrm{D}$ es un parámetro común para distintas fases aisladas individuales. Sin embargo, desde un punto de vista práctico, la aplicación del modelo de materiales de cemento tropieza con tres principales dificultades por resolver:

1) Generalmente, no se conoce la cantidad de fases probables de carbonatar en la muestra original. Además tampoco se conoce la cantidad de calcita producida cuando la muestra está completamente carbonatada. Sin embargo, se ha encontrado (Castellote et al., 2008) una relación lineal entre porcentaje de $\mathrm{CaO}$ del aglomerante y calcita formada $\left(\mathrm{mol} / \mathrm{cm}^{3}\right)$ cuando la carbonatación de $\mathrm{CO}_{2}$ está al $100 \%$ (serie b). Se ha informado (Castellote (a) et al., 2008) que cuando el proceso de carbonatación emplea distintas concentraciones de $\mathrm{CO}_{2}$, la cantidad total de calcita también es diferente. Por lo tanto, con la información proporcionada por los mismos autores en (Castellote (a) et al., 2008) (obtenida en muestras de cemento Portland - OPC), queda introducido (Castellote y Andrade, 2008) el concepto de "factores de reducción" (FR). Es necesario aplicar estos factores al modelo para carbonatar otras concentraciones de $\mathrm{CO}_{2}$ distintas al $100 \%$. $\rho_{\mathrm{s}}$ : Molar fraction of the reactant, $\mathrm{s}$, in the solid $\left(\mathrm{mol} / \mathrm{cm}^{3}\right)$

t: Time of experiment (seg)

$\tau$ : Time for complete conversion of the reactant $s$ (seg)

D: Effective diffusion coefficient of $\mathrm{CO}_{2}$ through the carbonated layer $\left(\mathrm{cm}^{2} / \mathrm{seg}\right)$

b : stoichiometric coefficient for the reaction: $b \mathrm{~S}(\mathrm{~s})+$ $\mathrm{CO}_{2} \rightarrow \ldots$.

$\mathrm{CC}_{\mathrm{O} 2}$ : Concentration of $\mathrm{CO}_{2}$ in the gas phase $\left(\mathrm{mol} / \mathrm{cm}^{3}\right)$

r: Radius of unreacted core $(\mathrm{cm})$

R: Radius of the cylinder $(\mathrm{cm})$

3.2 b) Adaptation and application of the model to cementitious materials using different concentrations of $\mathrm{CO}_{2}$

From the experimental data and the set of equations 1, 2 and 3, it is possible to determine the time for complete conversion of each phase, from which it is possible to deduce that even though for the same mix, the rate for the different phases is different, there is the same proportionality between each phase in the different samples (Castellote y Andrade, 2008). Providing that the diffusion of $\mathrm{CO}_{2}$ through the external carbonated part of the sample is the controlling step, the different are not due to different chemical reaction rates, but they are attributed to the different molar fraction of each phase reactant, being the $\mathrm{D}$ a common parameter for the different individual isolated phases. However, from a practical point of view, the application of the model to the cementitious materials encounters three main points to solve:

1) Usually, the amount of the different phases able to carbonate in the original sample is not known. In addition, the amount of calcite formed when the sample is fully carbonated is neither known. However, a linear relationship between the percentage of $\mathrm{CaO}$ in the binder and the $\mathrm{mol} / \mathrm{cm}^{3}$ of calcite formed when fully carbonating at $\mathbf{1 0 0} \% \mathrm{CO}_{2}$ (series b) has been found (Castellote et al., 2008). In (Castellote (a) et al., 2008), it was reported that when carbonating using different $\mathrm{CO}_{2}$ concentrations, the total amount of calcite formed was different. Therefore, from the data given in (Castellote (a) et al., 2008) by the same authors (obtained with OPC samples), the concept of "reductions factors", RF, was introduced (Castellote y Andrade, 2008). It is necessary to apply these factors to the model when carbonating at other $\mathrm{CO}_{2}$ concentrations different from $100 \% \mathrm{CO}_{2}$. 
Se debe destacar que si la muestra fuera mortero o hormigón, sería necesario introducir un factor adicional para corregir la cantidad de pasta en la muestra, FCP (este factor será explicado en detalle en la próxima sección) (Castellote y Andrade, 2008).

2) Por otro lado, para contar con un parámetro global, es necesario determinar en cada fase el promedio fraccional de conversión, también el promedio " $b$ ". Puesto que la mayor parte de la fracción carbonatada de la pasta está compuesta por portlandita y $\mathrm{CSH}$, pareciera razonable aproximar b como 1 en el proceso global. Además considerando que desde un punto de vista práctico, el procedimiento más conveniente y empleado en la medición de carbonatación es el indicador de fenolftaleína, se podría asumir que - aún cuando existe algún grado de predilección - estaría muy inclinado a la conversión fraccional del hidróxido de calcio (Rahman y Glasser, 1989).

3) Cálculo de D. No existe una relación directa entre D y porosidad total encontrada entre muestras carbonatadas ni las no carbonatadas (Castellote 2008). La única relación encontrada entre coeficiente de difusión y porosidad (\% vol), para las muestras carbonatadas, ha sido en el rango de poros entre 0.1 y $0.05 \mu \mathrm{m}$. Esto confirma que el paso controlador a través de la capa carbonatada, dificulta la predicción del coeficiente de difusión exactamente en el área porosa. En la muestra no carbonatada, la relación más aproximada fue encontrada en poros que son menores que $0.05 \mu \mathrm{m}$.

Para solucionar los inconvenientes prácticos, hipótesis han sido introducidas que explican los tres distintos puntos, éstas han sido analizadas y comprobadas a continuación: Primero, se ha calculado D para cemento Portland con valores reales (conversión promedio, b promedio y la $\rho$ s real), dando como resultado 5.1 E-6 $\mathrm{cm}^{2} / \mathrm{s}$. Luego, se ha obtenido el valor D usando la aproximación propuesta (conversión fraccional para hidróxido de calcio $b=1$, y $\rho$ s porcentaje estimado de $\mathrm{CaO}$ en el aglomerado), dando como resultado $\mathrm{D}=6.4$ E-6, bastante cercano al real y en el mismo orden de magnitud que aquellos en (Houst y Wittmann 2002).

\section{2 c) Validación}

La validación final del modelo se llevó a cabo empleando datos obtenidos con probetas de hormigón,
It has to be remarked that if the sample were mortar or concrete, it would be necessary to introduce an additional factor correcting the amount of paste in the sample, CFP, (this factor is explained in more detail in the next section) (Castellote y Andrade, 2008).

2) On the other hand, in order to have a global parameter to use it is necessary to know the averaged fractional conversion of each phase, as well as the averaged " $b$ ". Provided that most of the carbonated fraction of the paste is made of Portlandite and $\mathrm{CSH}$, it seems a reasonable approximation consider $b$ as $\mathbf{1}$ for the global process. In addition, considering that from a practical point of view the most convenient and used procedure for measuring the carbonation is the phenolphthalein indicator, it could be considered that, even though there is some degree of bias, it should be quite close to the fractional conversion for portlandite (Rahman y Glasser, 1989).

3) Calculation of $D$. There is not a direct relationship between the $D$ and the total porosity neither for the carbonated samples nor for the uncarbonated one (Castellote 2008). The only relationship found between the diffusion coefficient and the porosity (\% vol) has been, for the carbonated samples, in the range of pores between the 0.1 and 0.05 $\mu \mathrm{m}$. This confirms the controlling step through the carbonated layer, and makes a bit difficult to be able to predict a diffusion coefficient just from porosity data. For the uncarbonated sample, the most approximated relationship found has been for the range of pores smaller than $0.05 \mu \mathrm{m}$.

To undertake the practical inconveniences, the assumptions that have been introduced when explaining the three different points, have been analysed and tested as follows: First of all, the D for OPC with the actual values (averaged conversion, averaged $b$ and actual $\rho s$,) has been calculated, which gives a value of $5.1 \mathrm{E}-6 \mathrm{~cm}^{2} / \mathrm{s}$. Then, it has been obtained the value for $D$ using the proposed approximation (fractional conversion for portlandite, $b=1$, and $\rho_{s}$ estimated from the percentage of $\mathrm{CaO}$ in the binder, which gives $\mathrm{D}=6.4 \mathrm{E}-6$, which is quite close to the real one, and of the same order of magnitude as those given in (Houst y Wittmann 2002).

\section{2 c) Final Validation \\ The final validation of the model was carried out with data from concretes specimens,}


a fin de comprobar también la extrapolación de pasta a hormigón (Castellote 2008). Para estos efectos y tal como se ha indicado anteriormente, para obtener una adecuada $\rho s\left(\mathbf{m o l} / \mathbf{c m}^{3}\right)$ es necesario introducir un factor corrector a la cantidad de pasta en la muestra de cemento Portland, siempre que se conozca la proporción de mezcla del hormigón.

Además, en todos los casos se ha empleado un valor genérico de $1.7 \mathrm{gr} / \mathrm{cm}^{3}$ para la densidad fraccional de la pasta.

El caso de validación aquí presentado, emplea información de la literatura (Sanjuan et al., 2003). Las proporciones de mezclas para dos composiciones distintas de hormigón (tipo A y B, serie I en Sanjuan et al., 2003) y dos condiciones muy diferentes en las pruebas de carbonatación, son presentadas a continuación: 5 días al $\mathbf{1 0 0} \%$ de $\mathrm{CO}_{2}$ y dos años a exposición natural. De los resultados obtenidos en condición acelerada, el modelo ha sido aplicado para determinar la profundidad de la carbonatación bajo condiciones naturales, después de dos años.

Para estos dos hormigones, el factor de corrección ha sido calculado en una muestra de 0.25 y $0.31 \mathrm{~cm}^{3}$ pasta $/ \mathrm{cm}^{3}$ y $\mathrm{D}_{\mathrm{CO} 2}$ de $2.11 \mathrm{E}-4 \mathrm{~cm}^{2} / \mathrm{s}$ y $1.10 \mathrm{E}-$ $4 \mathrm{~cm}^{2} / \mathrm{s}$ para los hormigones $A$ y $B$, respectivamente. Estos coeficientes son menores pero tienen el mismo orden de magnitud que se ha obtenido para la aplicación de los modelos Tuuti, 1982 y Bakker 1964 (calculados en Sanjuan et al., 2003).

Los resultados de la validación son mostrados en la Figura 4, donde se puede observar que, aún cuando ambas condiciones son diferentes y extremas, los resultados experimentales y los previstos para ambos hormigones son muy buenos. in order to validate also the extrapolation from paste to concrete (Castellote 2008). For doing that, as already said, in order to obtain the righps $\left(\mathrm{mol} / \mathrm{cm}^{3}\right)$ it is necessary to introduce a factor correcting the amount of paste in the sample, CFP, provided the mix proportion of the concrete is known.

In addition, a generic value for the density of the paste fraction of $1.7 \mathrm{gr} / \mathrm{cm}^{3}$ has been used for all the cases.

The case of validation presented here uses data from literature (Sanjuan et al., 2003). Mix proportions for two different compositions of concrete (type A and B, series I in Sanjuan et al., 2003) and two very different conditions for the carbonation tests are given: 5 days at $100 \% \mathrm{CO}_{2}$ and 2 years at natural exposure. From the data obtained from the accelerated condition, the model has been applied to determine the depth of carbonation in natural conditions after two years.

For these two concretes, the calculated CFP's have been of 0.25 and $0.31 \mathrm{~cm}^{3}$ paste $/ \mathrm{cm}^{3}$ sample, and $D_{\mathrm{CO} 2}$ of $2.11 \mathrm{E}-4 \mathrm{~cm}^{2} / \mathrm{s}$ and $1.10 \mathrm{E}-4 \mathrm{~cm}^{2} / \mathrm{s}$ for concretes $A$ and $B$ respectively. These coefficients are lower but of the same order of magnitude than that obtained by application of the models Tuuti, 1982 and Bakker 1964 (calculated in Sanjuan et al., 2003).

The results for the validation are given in Figure 4, where it can be seen that even though the conditions of the two different conditions are the extreme ones, the experimental data and the predicted ones for both concretes are very good.

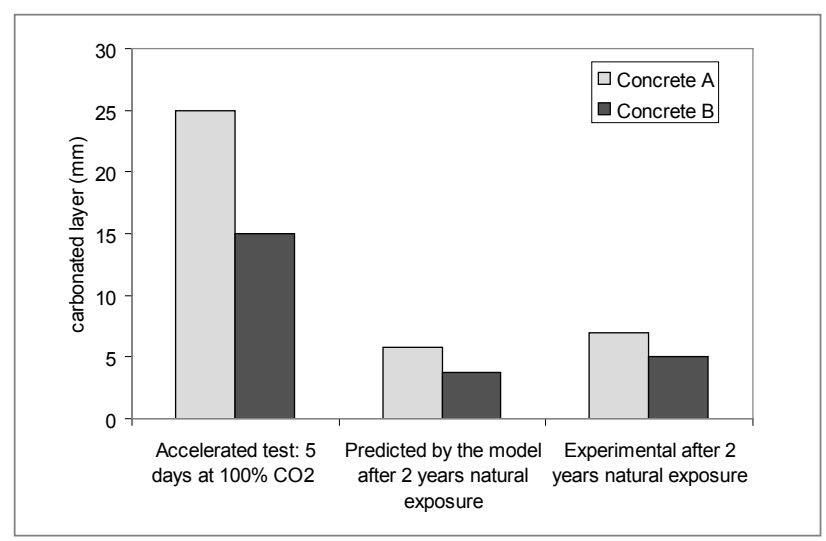

Figura 4. Validación del modelo para muestras de concreto: Datos obtenidos con experimento acelerado y con predicción en condiciones naturales (datos de Sanjuan et al., 2003)

Figure 4. Validation of the model for concrete samples: Data from accelerated experiment and prediction for natural conditions (data from Sanjuan et al., 2003) 


\section{Conclusiones}

Este artículo presenta un resumen de los elementos esenciales del modelo de carbonatación en matrices de cemento, cuyo desarrollo ha sido posible empleando monitoreo in-situ, difracción acelerada, pruebas de carbonatación acelerada, concentraciones de $100 \%$ de $\mathrm{CO}_{2}$, pastas de cementos de distintos aglomerantes.

Por una parte, los experimentos con modelos adquiridos y simultáneos de difracción de neutrones, permitieron monitorear las principales características de las pruebas. Por otra parte, el primer paso para desarrollar el modelo ha sido establecer el paso controlador en el índice global de carbonatación, ajustando las curvas de conversión fraccional experimentales a las ecuaciones teóricas. Como resultado, se ha demostrado que el paso controlador es la penetración y difusión del gas a través de la capa de ceniza hacia la superficie del núcleo aún sin reaccionar (difusión de $\mathrm{CO}_{2}$, a través de la parte externa carbonatada de la muestra). Luego el modelo ha sido aplicado a materiales de cemento, empleando diferentes concentraciones de $\mathrm{CO}_{2}$. Para estos efectos, se han introducido algunas hipótesis y factores: Factores de Reducción - FR, debido a que a mayor cantidad de material alcalino carbonatado, mayor es la concentración de $\mathrm{CO}_{2}$ y el factor corrector de pasta FCP (que corrige la cantidad de pasta en la muestra para los morteros o hormigones utilizados). Finalmente, el modelo ha sido validado con resultados empleando diferentes concentraciones (tomados de la literatura) y parecen ser lo suficientemente confiables para su aplicación en materiales de cemento, permitiendo extrapolar los resultados de experimentos acelerados a predicción en condiciones naturales.

\section{Agradecimientos}

Los experimentos realizados fueron posibles gracias al programa (Exp 5-25-50) facilitado por el Institute Max von Laue - Paul Langevin (ILL). Los autores están especialmente agradecidos del equipo D20. Loa autores también agradecen los fondos suministrados por el gobierno español, a través del proyecto CONSOLIDERSEDUREC.

\section{Conclusions}

This paper presents a summary of the essentials of a model for the carbonation of cementitious matrixes (UR-CORE), whose development has been possible through the in situ monitoring, by neutron diffraction, of accelerated carbonation tests, at $100 \% \mathrm{CO}_{2}$ concentration, of cement pastes of different binders.

On one hand, carbonation experiments with simultaneous acquisition of neutron diffraction patterns has allowed to monitor the major features of the experiments. On the other hand, the first step for developing the model has been the establishment of the controlling step in the global carbonation rate, by adjusting the experimental fractional conversion curves to the theoretical equations. As a result, it has been demonstrated that the controlling step is the penetration and diffusion of the gas through the ash shell to the surface of the core not yet reacted (diffusion of $\mathrm{CO}_{2}$ through the external carbonated part of the sample). Then, the model has been applied to the cementitious materials using different concentrations of $\mathrm{CO}_{2}$. For doing that, some assumptions and factors have been introducing: the Reduction Factors, RF (due to the fact that more amount of alkaline material is carbonated as higher is the concentrations of $\mathrm{CO}_{2}$ ) and the CFP, factor correcting the amount of paste in the sample, if mortar or concrete is used. Finally, the model has been validated with laboratory data at different concentrations (taken from literature) and it seems to be reliable enough to be applied to cementitious materials being able to extrapolate the results from accelerated tests to predict natural conditions.

\section{Acknowledgements}

The experiments reported here were done thanks to the beamtime (Exp 5-25-50) granted by the Institute Max von Laue - Paul Langevin (ILL). The authors are especially grateful to the staff of D20. The authors also acknowledge the funding provided by the Spanish government through the project CONSOLIDER-SEDUREC 


\section{Referencias / References}

Adrian R. Brough, Christopher M. Dobson, lan G. Richardson et al., (1994), “Application of selective 29Si isotopic enrichment to studies of the structure of calcium silicate hydrate (C-S-H) gels," J. Am. Ceram. Soc. 77 [2], 593-6.

Alekseev S.N., and Rozental N.K. (1976), "Corrosion vonstahlbeton in aggressive industrielft, Beton," 65.

Alonso C., y Andrade C., (1987), "Efecto que el tipo de cemento y la dosificación del mortero ejercen en la velocidad de corrosión de armaduras embebidas en mortero carbonatado," Mat. De Construc. 37 [205], 5-15

Alonso C., Andrade C., and Gonzalez, J.A., (1988), "Relation between resistivity and corrosion rate of reinforcements in carbonated mortar made with several cement types," Cem. Concr. Res. 18 [5], 687-98.

Andrade C., Alonso C., Arteaga A., Tanner P. (2000), Methodology based on the electrical resistivity for the calculation of reinforcement service life, Proceedings of the 5th CANMET/ACI International Conference on Durability of Concrete, June 4-9, 2000, Barcelona, Spain, (Ed. by V.M. Malhotra, ACI, 2000), Supplementary paper, pp 899-915.

Bakker R. (1964), "Prediction of service life reinforcement in concrete under different climatic conditions at given cover, Corrosion and protection of Steel in Concrete, Int. conference (R.N. Swamy (Ed) . Sheffield.

Berger RL (1979), "Stabilisation of silicate structure by carbonation," Cem. Concr. Res. 9 [5], 649-65.

Z Sauman and V Lach, "Long term carbonization of the phases 3CaO.Al2O3.6H2O and 3CaO.Al2O3.4H2O," Cem. Concr. Res. 2, 435-446.

Bier T.A., Kropp J., and Hilsdorf H.K., (1989), "The formation of silica gel during carbonation of cementitious systems containing slag cements," Am. Concr. Inst. SP [114], 1413-28.

Castellote M (a) et al., Fernández L., Andrade C., Alonso C. (2008), "Chemical changes and phase analysis in carbonated OPC paste at different CO2 concentrations". Mat and Structures (2008) DOI: 10.1617/s11527-008-9399-1

Castellote M., and Andrade C. (2008), Modelling the carbonation of cementitious matrixes by means of the Unreacted-Core Model, UR-CORE, Cement and Concrete Research 38 (2008) 1374-1384, DOI :10.1016/j.cemconres.2008.07.004

Castellote M., Andrade C., Turrillas X., Campo J.,Cuello G. J. (1973), Accelerated carbonation of cement pastes in situ monitored by neutron diffraction, Cement and Concrete Research 38 (2008) 1365-1373, DOI : 10.1016/j.cemconres.2008.07.002

Cole W. F. and Kroone B. (1969), “Carbonate Minerals in Hydrated Portland Cement," Nature 4688, 59 (1959).

Cole W. F. and Kroone B. (1960), "Carbon dioxide in Hydrated portland Cement.," J. Am. Conc. Inst. 31, 1275-1295 (1960).

Claisse P. A., Hanaa El-Sayad and Ibrahim G. Shaaban (1999), "Permeability and pore volume of carbonated concrete," ACI Mater. J. 96 [3], 378-381 (1999).

Chaussadent T., Baroghel-Bouny V., Hornain H. et al., (2000), "Effect of water-cement ratio of cement pastes on microstructural characteristics related to carbonation process," Am. Concr. Inst., SP, SP 192 [Durability of Concrete, Vol. 1], 523-537 (2000).

Dunster A. M. (1989), "An investigation of the carbonation of cement paste using trimethylsilylation," Adv. Cem. Res. 2 [7], 99-106 (1989).

Funato M., Hashimoto M. and K. Shouichi. (1991), "Study on quantitative analysis of silica gel formed by carbonation of cement hydrates," Semento, Konkurito Ronbunshu 45, 252-7.

Geoffrey W. Groves, Brough A., lan G. Richardson et al. (1991), "Progressive changes in the structure of hardened C3S cement pastes due to carbonation," J. Am. Ceram. Soc. 74 [11], 2891-6 (1991).

Gonzalez J. A., Algaba S. and Andrade C. (1980), "Corrosion of reinforcing bars in carbonated concrete," Br. Corros, J. 15 [3], $135-139$ (1980). Gonzalez J. A. and Andrade C. (1980), "Relaciones cuantitativas entre la carbonatación y la corrosión de armaduras," Corrosion y protección Feb, 15-24 (1980).

Gonzalez J. A., Andrade C. and Alonso C., (1983), "Corrosion rate of reinforcements during accelerated carbonation of mortar made with different types of cement.," in Corros. Reinfc. In Conc. Const, edited by A.P. Crane (1983), Vol. Chapter 11, pp. 159-174.

Goto S., Nakamura A. and loku K. (1998), "Hardening of calcium silicate compounds by carbonation," Muki Materiaru 5 [272], 22-27 (1998) Groves G. W., Rodway D. I. and Richardson I.G. (1990), "The carbonation of hardened cement pastes," Adv. Cem. Res. 3 [11], 117-25.

Houst Y. F. and Wittmann F. H. (2002), "Depth profiles of carbonates formed during natural carbonation" Cem. Concr. Res. 32, 1923-1930.

International Tables for X-Ray Crystallography (1993), Volume II, Mathematical tables. Ed. by U. Shmueli. published by Kluwer Academic Publishers, Dordrecht / Boston / London.

JCPDS International Centre for Diffraction Data (JCPDS-ICDD 2000), PDF number 35-0772; Natl. Bur. Stand. (US) Monogr. 25, $21,72$.

Johannesson B. and Utgenannt P. (2001), "Microstructural changes caused by carbonation of cement mortar," Cem. Concr. Res. 31 [6], $925-931$.

Kobayashi, K. Suzuki and Y. Uno (1994), "Carbonation of concrete structures and decomposition of C-S-H," Cem. Concr. Res. 24 [1], 55-61

Kokubu M. and Nagataki S. (1989), "Carbonation of concrete with fly ash and corrosion of reinforcements in 20-years test.," presented at the Third ICFSS, Trondheim. Massazza F. (1999), "Pozzolanas and durability of concrete," Cimento Beton Dunyasi 3 [21], 19-44.

Ngala V. T. and Page C. L. (1997), "Effects of carbonation on pore structure and diffusional properties of hydrated cement pastes," Cem. Concr. Res. 27 [7], 995-1007.

Nishikawa T. and Suzuki K. (1991), "Carbonation of calcium silicate hydrate," Semento Konkuriito [528], 32-9.

Nishikawa T. and Suzuki K. (1994), “Chemical conversion of C-S-H in concrete," Cem. Concr. Res. 24 [1], 176-82 .

Parrot L. J. (1994), "Design for avoiding damage due to carbonation -included corosion-. SP-145-15. Int. Congress on Durability of Concrete (Malhotra (Ed), Nice, CANMET, 1994, pp 283-298.

Parrott L. J. (1992), “Carbonation, moisture and empty pores,” Adv. Cem. Res. 4 [15], 111-18 (1992).

Pihlajavaara S. E. (1968), "Same results of the effect of carbonation on the porosity and pore size distribution of cement paste," Mat. et Cons. 1 [6], 521-526 (1968), Pihlajavaara S. E. and Pihlman E. (1974), "Effects of carbonation on microstructural properties of cement stone," Cem. Concr. Res 4 [2], $149-154$. Rahman A. A. and Glasser F. P. (1989), "Comparative studies of the carbonation of hydrated cements," Adv. Cem. Res. 2 [6], 49-54 Richardson I. G., Groves G. W. and Brough A. R. et al. (1993), "The carbonation of OPC and OPC/silica fume hardened cement pastes in air under conditions of fixed humidity," Adv. Cem. Res. 5 [18], 81-6 (1993).

Reardon E. J., James B.R. and Abouchar J. (1989), “High pressure carbonation of cementitious grout," Cem. Concr. Res. 19 [3], $385-99$ Sangkyu K., Hisashi T., Yoko Ohba et al. (1995), "Carbonation of calcium hydroxide and calcium silicate hydrates," Muki Materiaru 2 [254], 18-25 Sanjuan M.A., Andrade M.C. and Cheyrezy M. (2003), “Concrete carbonation tests in natural and accelerated conditions," Adv. In Cem. Res. 15, No 4, October, (2003), pp 171-180.

Sergi G. (1986), “Corrosion of Steel in Concrete: Cement Matrix Variables. PhD thesis," , Aston University, 1986.

Shirakawa T., Shimazoe Y., Aso M. et. al. (1999), "Prediction of carbonation progress of cement mortar based on diffusion equation of carbon dioxide," Semento, Konkurito Ronbunshu 839 [English] (1999).

Smolczyck H.G. (1968), "Discussions to M. Hamada's paper "Neutralization (carbonation) of concrete and corrosion of reinforcing steel"," presented at the Proc. 5th Int. Sym. Chem. Cem., Tokyo, 1968.

Suzuki K., Nishikawa T. and Tomonobu H. (1989), “Carbonation of calcium silicate hydrates (C-S-H) having different calcium/silicon ratios," Semento, Konkurito Ronbunshu [43], 18-23

Taylor H. F. W. (1990), Cement Chemistry (Academic Press, London, UK, 1990).

Tokyay M. (1997), "Cement systems in aggressive environments," Cimento Beton Dunyasi 2 [8], 13-19.

Tuuti K. (1964), "Corrosion of Steel in Concrete, PhD thesis, Swedish Cement and Concrete Research Institute (CBI), Stockholm, 1982.

Yousuf M., Mollah A. Thomas R. Hess, Yung Nien Tsai et al. (1993), “An FTIR and XPS investigation of the effects of carbonation on the solidification/stabilization of cement based systems - portland Type V with zinc," Cem. Concr. Res. 23 [4], 773-74 (1993).

Verbeck, G. (1958), “Carbonation of hydrated portland cement," PCA Bulletin 87, 17-36 (1958).

Venuat M., and Alexandre J. (1968), "De la carbonatation du béton.," Rev. Mater. Const. , 421-481 (1968).

Weber H. (1983), "Methods for calculating the progress of carbonation and the associated life expectancy of reinforced concrete components," Betyonwerk + FertigteilTechnik 8, 508-514 (1983). 